\title{
THE CONCEPT OF A BUSINESS MODEL FOR AN AIR CARRIER IN SLOVAKIA
}

\author{
Radovan Baláž \\ Faculty of Aeronautics, Technical University of Košice, Slovakia \\ Email: radovan.balaz@,tuke.sk
}

Received: 5 August 2021. Revision received: 21 November 2021. Accepted: 20 December 2021

\begin{abstract}
Determining the operating airline's business model is among the strategic decision, particularly for emerging airlines. A suitable and correct business model is an essential prerequisite for the company to establish itself in the market and be competitive successfully. This paper aims to design a specific business model for an air carrier, considered a national air carrier in Slovakia. Slovakia currently has no national air carrier, which would contribute to the development of passenger air transport and would reflect the domestic population's current needs and help increase inbound tourism. The main goal of the designed air carrier is to contribute to the development of air transport in Slovakia and transport a higher number of air passengers, reaching at least an average increments as in other European Union countries. This study proposes a business model framework applied to the conditions of Slovakia, which analyzes the main trends identified in the literature for designing business models for airlines abroad. In examining various studies, we have identified aspects of business models and the main models used by airlines abroad. We used general methods to process information and assess current trends in air transport. In the study, we apply the list method and the inventory method, focusing on new trends and process management methods in the aviation industry. Finally, we developed a business model for a potential air carrier operating in Slovakia from the acquired knowledge.
\end{abstract}

KEYWORDS: Business model, Air carrier, Hybrid airline, Full-service carrier, Low-cost carrier.

JEL CLASSIFICATION: L93, M20, M30.

Reference: Balaz, R., (2021). The concept of a business model for an air carrier in Slovakia. International Journal of Entrepreneurial Knowledge, 9(2), 96-108. doi: 10.37335/ijek.v9i2.137

\section{INTRODUCTION}

The aviation industry is one of the most global sectors and has a major impact on economic growth, and is an essential part of the global and national economy. It affects the development of individual countries and regions, tourism development, helps develop international trade, and connects countries and states by fast and safe transport. The development and increasing demand for this type of transport are also growing in Slovakia, even though we are significantly behind the world trend in transporting passengers. One of the reasons is the absence of a domestic air carrier, which would reflect the domestic population's needs. Such a carrier would operate charter services and scheduled airlines, whether international or domestic. Slovakia, together with Lithuania, are the last two countries in the entire European Union that do not have their own national air carrier. The article's main goal is a comprehensive proposal of a suitable business model that an air carrier will operate in Slovakia. The proposed business model will contain precisely defined characteristics and approaches to the company's management. We will take into account the current competition in the market and the latest trends in the airline's operation. The business model concept is an important and strategic decision and will have a significant impact on its competitiveness in the market. The type of business model in the aviation industry is determined by how the airline operator generates revenues, such as the level of services provided, the amount of added value, and the characteristics of the target customers. Market deregulation and the constant increase in the competition are forcing airlines to constantly adjust their business model and adapt to the conditions of the industry. The article will also list the potential risks and threats that will affect the proposed business model. In 2018, the Government of the Slovak Republic submitted a request to prepare an analysis of the possibility 


\section{INTERNATIONAL JOURNAL OF ENTREPRENEURIAL KNOWLEDGE}

Issue 9, volume 2, ISSN 2336-2960 (Online)

www.ijek.org

of establishing a national air carrier (Národohospodárska fakulta, 2018). In this analysis, a business model of the air carrier was also marginally proposed, which, according to the authors of this analysis, should take the form of a low-cost carrier (LCC). Few studies and professional works are elaborate on this topic in Slovakia. One of the few studies is an article (Jakubík et al., 2020), which also proposes a business model for a national air carrier in Slovakia. In this study, the authors proposed a hybrid airline's business model.

In our article, we followed up on the published studies in Slovakia, and in the research, we also applied the latest knowledge and trends in airline management. In foreign studies, the design of a business model is one of the most frequently researched topics. Authors often study the conceptualization of business models (Massa et al., 2017), or changes and optimizations of the business model (Cozzolino et al., 2017; Sund et al., 2014). If any sector of the national economy is to succeed, it must constantly adapt to current customer requirements and be characterized by a certain level of innovation. As a result, new market opportunities may arise that disrupt the current situation, changing the industry (Corbo et al., 2016). In the aviation industry, we can consider the birth of the first low-cost carrier - Southwest Airlines in the USA- as a fundamental change in the market, and later others emerging that used the LCC business model. This example clearly indicates that there are different ways in which airlines seek to increase their capacity and gain a competitive advantage significantly. Gaining a competitive advantage using new business models can also be identified in the following studies (Achtenhagen et al., 2013; Markides et al., 2013). In another study (Chesbrough 2010), the author analyzes the functionality of individual business models and their benefits.

\section{THEORETICAL BACKGROUND}

Own air transport is performed by air carriers that operate aircraft. Their customers are individuals, travel agencies, companies or entrepreneurs. For their activities, they need a number of specialized professions as well as external suppliers, which include individual airports and air traffic control companies. Due to the nature of their activities and the liberalization of the business environment in air transport, most carriers today operate in developed markets in a highly competitive environment. As a result, each of them must make fundamental decisions regarding the focus of its services (regular / irregular, passenger / freight, domestic / international, classic / low-cost, regional / long-distance) and, together with this, shape the overall strategy and trade policy (Tobisová, 2014).

The term "business model" does not have a clear definition, it is rather part of business jargon. The term "business model" was originally used in the internet business sector and was later transferred to other sectors. It is often stated in the literature that, the term business model does not have a generally accepted definition and is interpreted with various relevant ones (Zott et al., 2011; DaSilva et al., 2014; Massa et al., 2017; Foss et al., 2018). According to one definition, a business model is considered a necessary part of all businesses. A detailed understanding of the business model is also valuable as a company seeks to change its strategic position in the value chain, according to another literature (Nenonen et al., 2010). According to this literature (Chesbrough, 2010), the business model matters because a better business model often outperforms a better idea or technology. The basic characteristics for the business model are:

- formulate a value proposition,

- identification of market segments,

- define the structure of the value chain within the company,

- estimation of cost structure and profit potential,

- description of the company's position in the value network,

- formulate a competitive strategy. 


\section{INTERNATIONAL JOURNAL OF ENTREPRENEURIAL KNOWLEDGE}

Issue 9, volume 2, ISSN 2336-2960 (Online)

www.ijek.org

The business model mediates the flow of information between the technical and economic field and, with the help of these six components, transforms technical inputs into economic outputs. Based on business model definitions (Laasch, 2018; Ocasio et al., 2016; Foss et al., 2015; Teece, 2010), it is possible to define an airline's business model as the way it operates in passenger and freight transport. We can also characterize airlines according to the way they provide and present their services. This can give us elements about their business model. The general framework of business models can be determined by the strategic purpose, vision or mission of airlines with basic elements of business identity. In this case, the strategic intent statements and the company information it provides may provide some information about the business model. We can characterize airlines according to the way they provide and present their services. This can give us elements about their business model. The general framework of business models can be determined by the strategic purpose, vision or mission of the airlines, with the basic elements of business identity. In this case, the statements of strategic intent and the information about the company it provides may provide some information about the business model.

About the business model of the airline full-service carrier (FSC) strives to provide comprehensive services for its passengers. Although there are many differences between operators, there are some basic characteristics that all airlines have in common. The basic characteristic of the FSC is the offer of transport and transfers within the network in cooperation with other carriers (transport system referred to as "hubs and wire curves"). The main goal of the FSC is to fully cover the greatest possible demand for destinations, through optimized flights and hubs. Each FSC has invested heavily in building processes and systems to establish a connection with the global airline system. They offer their customers flights that can transport passengers to their destination, even if it requires several transfers. Such an offer of comprehensive transport services with high connectivity is still in demand by a large number of passengers. Many airlines have entered into alliance agreements and are members of one of the airline alliances. Such membership in the alliance allows for even closer cooperation between airlines, better coordination of flights and ancillary services and, last but not least, they can offer lower ticket prices. Such a business model also has its disadvantages and that is the high cost of the network system.

The low-cost carrier (LCC) business model focuses primarily on passenger groups that do not require a high level and quality of service, nor do they require an extensive route network. These passengers use the services provided by LCC airlines. The LCC business model originated in the United States in the 1970s. Southwest Airlines is considered to be the first LCC company. This business model penetrated Europe in the 1990s, when the Irish company Ryanair began flying in 1995 and began to compete directly with traditional airlines in Europe. The development of LCC was mainly due to market deregulation and the reduction of various air traffic restrictions by individual governments and authorities. The increase in capacity at airports also had a great impact. These are mainly so-called secondary airports, where airport charges are incomparably lower than at large airports. LCCs have fundamentally changed the aviation industry and the way it travels. In liberalized markets that were previously controlled and dominated by the FSC, the LCC has gained significant influence and market share over time. The basic characteristic of LCC is the reduction of costs to a minimum and the offer of the lowest ticket price on a given route. Each airline must comply with the regulations and laws concerning the safe operation of air traffic and follow the instructions of the air traffic control authorities. Therefore, there are no savings in aircraft maintenance or costs associated with increasing flight safety. LCCs need to reduce operating costs in other areas of their business. One of the main factors contributing to cost reduction is the low level of services provided and passengers generally do not receive any benefits. Which in practice means they don't have to pay for them. No additional services are included in the standard ticket price. If passengers are interested in some additional services, they are charged. Low cost airlines are characterized by the use of one type of aircraft on all airlines. Such a single fleet allows for significant reductions in maintenance costs, on-board staff training costs and volume discounts from aircraft manufacturers when procuring new machinery. This significantly reduces the flexibility of fleet utilization according to current demand. The flight schedule is also planned to suit the structure of the aircraft fleet. There are no connecting 


\section{INTERNATIONAL JOURNAL OF ENTREPRENEURIAL KNOWLEDGE}

Issue 9, volume 2, ISSN 2336-2960 (Online)

www.ijek.org

flights or network connections in this business model. Low cost airlines only offer a point-to-point system. Passengers wishing to use connecting flights must re-register at their transit airport and proceed to their destination at their own expense.

With ever-changing times and changes in the industry, airlines have also had to adapt their business models and management approaches. Business models and related services for passengers to the stage where there is a mixing business models. From the traditional low-cost business model of operating an airline, a new business model has emerged - the hybrid airline. Hybridization of aviation business models through taking elements from other business strategies into your. These companies tend to emphasize a higher level of service provided, but with a view to constantly reducing costs, as with LCCs themselves. There are also examples where, as an airline, it has a similar structure to the FSC. The hybrid business model is beginning to be accepted among different groups of people, whether middle-class or so-called business travelers. The hybrid airline takes the elements of a different business strategy into its own and adapts it to its own needs. At the same time, these companies place emphasis on a higher level of services provided with an emphasis on cost savings than in LCC. This business model is starting to be used by several LCCs that are trying to gain new customers this way. Airlines that currently use this business model include Germanwings, Southwest Airlines and JetBlue. These companies are already classic LCCs because they use some elements typical of the FSC business model in their activities. Some have begun to expand cooperation with other aviation operators, and code-share agreements have been concluded. This has created smaller global networks and can offer better air connections. Which gave them access to new markets. They have customized how tickets are sold and use several distribution channels to sell at the same time and not just their own website. These processes of change and hybridization of the business model also affect the FSC. In the past, it was almost inconceivable for the FSC to charge for food and drink served on board, transported luggage, seat selection, and so on. The classic FSC with a high level of service and passenger care system, differentiated by aircraft fleets and airlines, has more staff and time-consuming day-to-day business activities. However, their services are needed and will remain in demand in the future. But they will have to keep up with the simple constructions and low costs they have with LCC. For this reason, it seeks to implement elements in its processes that aim to reduce costs while maintaining a high standard of services offered. Some of the airline's networks are beginning to unify the aircraft fleet, thus reducing costs. For example, the aircraft operator Emirates, whose aircraft fleet consists of 263 aircraft parts and consists of only two types of aircraft, namely Airbus A380-800 and Boeing 777- 300ER. This contributes to reducing the cost of flight crew training, more efficient maintenance and service. And last but not least, better pricing conditions in quantitative purchases, which save considerable funds. High airport charges at major airports have also contributed to the traditional FSC business model. Therefore, some network airlines use a secondary airport that is not too far from the city center and does not disturb them by customers. Airport charges are lower than at large airports, which significantly contributes to reducing operating costs. In recent years, new distribution channels will be used, mainly related to the development of information technology and available online. This allows passengers to directly purchase a ticket directly from the airline, for example, through their own applications and do not have to use the services of travel agents. This hybrid business model combines cost-effective pure LCC methods with service offering, flexibility and carrier structure with full-service routes. These hybridization means that airlines, especially FSCs, target a wider range of customers. Some large airlines, known as FSC, have decided to set up their own LCC within their group. Lufthansa founded by LCC Eurowings or the KLM group of its own subsidiary Transavia. By using different combinations of both business models, they seek to streamline service delivery.

Increasing competition has forced airlines to constantly adapt. This trend is also supported by anothers studys (Franke, 2007; Daft et al., 2013; Lohmann, 2018). The main business models in air transport are based on low-cost or full-service strategies. Models based on low-cost strategies are characterized by value creation by focusing on what is necessary for the value offer for the passenger. Cost savings are shared with the client and usually lead to a customer base with less purchasing power (Gassmann et al., 


\section{INTERNATIONAL JOURNAL OF ENTREPRENEURIAL KNOWLEDGE}

Issue 9, volume 2, ISSN 2336-2960 (Online)

www.ijek.org

2014). New ways and approaches to management have been proposed, resulting in new business models that differ from traditional classifications. These airline business models are hybridization. The arrival of low-cost carriers in the aviation industry was one of the most important impulses for changes in the aviation industry. Recently, however, various of these airlines have begun to adjust their practices (Massa et al. 2013), change their management approach and modify their business models. Which resulted in different types of business models. Some have gradually deviated from the classical classification to include a hybrid approach (Fageda et al., 2015). Other carriers, in turn, have adapted their business model by applying the principles of a low-cost business model in an even stronger way. It consists mainly of adding or removing activities, a process known as reactivation of the business model (Santos et al., 2009). Klophaus (2012) states in his study, that many airlines are trying to change or improve their business strategy. Therefore, most European airlines adopt a hybrid business model strategy, that changes key elements of their core business model. According to Turčan (2020), the hybrid business model of these carriers is accepted among both business and middle class passengers. Lohmann et. al (2013) in his study summarized data from 9 major US carriers, analyzed and summarized the main features of each business model in terms of revenue, connectivity, comfort, convenience, aircraft use and work. This research has shown a growing number of hybrid airlines with low ticket prices. They achieve low operating costs, offer low ticket price and have attractive operating profit margins.

In order to reduce costs, streamline management and increase labor productivity, this trend is also reflected in traditional airlines, which are beginning to apply the procedures typical of low-cost airlines. Conversely, low-cost airlines are beginning to implement features that are typical of a traditional carrier's business model. The only goal is to increase one's own competitiveness. Based on the degree of hybridization of business models, we can divide air carriers in scheduled air transport into (Klophause, 2012; Turčan et al., 2020):

- low cost carriers,

- hybrid carriers with the predominant attributes of a low-cost business model

- hybrid carriers with predominant attributes of the traditional business model,

- traditional carriers.

Low-cost companies have been gaining in popularity over the last 15 years, but these companies are not providing a higher level of service. A higher level of service is required by a large proportion of passengers who do not want to use the expensive FSC services, but are willing to pay extra for a higher level of service. Therefore, the interest of these passengers is directed to the hybrid business model. In an expert article (Pereira et al., 2015), the authors suggest that a company offering a higher level of service at lower prices than FSC stimulates demand and can reach new passengers.

In another scholarly article (Markides et al., 2013), they emphasize the competitive advantage gained by airlines with new business models in markets created by companies (like low-cost), where the introduction of a new business model has distorted the advantages of pioneering airlines. New airline models have the potential to undermine the sustainability of incumbents, regardless of where they operate. An example of a successful hybrid business model is Southwest Airlines. The company's new idea was based on the assumption that most customers want direct flights, at a relatively low cost. However, they require reliability and good customer service, but they do not need the "embellishments" offered by FSC. The aircraft fleet were standardized, which allowed for greater efficiency and operational flexibility. Southwest's business model was completely different from that of existing major airlines (Teece, 2010).

The emergence of different business models is a consequence of phenomena such as globalization, liberalization and deregulation. These factors have affected airlines to adapt their flight networks and incorporate new elements into their business models. It can be stated that existing business models have evolved based on their characteristics (Corbo, 2017; Daft et al., 2015) and new types of airline business models have emerged (Urban et al., 2018; Wensveen et al., 2018). 


\section{INTERNATIONAL JOURNAL OF ENTREPRENEURIAL KNOWLEDGE}

Issue 9, volume 2, ISSN 2336-2960 (Online)

www.ijek.org

\section{AIM AND METHODOLOGY}

The main goal of the study is to design a competitive business model of a potential air carrier in Slovakia, which would be helpful in the development of air transport in Slovakia in the future. Another partial goal is to analyze the current situation in air transport and subsequently identify a possible gap in the Slovak market. Therefore, we are looking for an answer to the main question:

"What business model will be competitive?"

In addition to the main research question, we can formulate sub-questions, which are as follows:

"What airlines currently in the market have business models?"

"What threats and risks will affect the success of national air transport?"

In designing a suitable business model, we based on the current situation in air transport in Slovakia, the purchasing power of the domestic population and the demands of Slovak passengers. When creating the concept, we also had to take into account the relative proximity of other airports, especially WienSchwechat Airport and the airlines that use this airport. As they will represent strong competition. In the evaluation and analysis, we also relied on the operation of airlines in Slovakia in the past. In creating the proposal itself, we used the experience of respondents, who work or have worked in the aviation industry in various management positions. Through interviews with respondents and taking into account the data obtained, we formulated detailed elements that would form the concept of the business model. The concept contains current trends and knowledge in the field of civil aviation, compares different types of business models and adapts individual elements, approaches and forms of management to current market conditions in Slovakia. In addition to a theoretical approach to the issue, we processed the knowledge gained from the surrounding countries and applied it appropriately for the needs of the Slovak market. We analyzed the individual types of business models in the conditions of the Slovak aviation market. We have presented arguments for individual types of business models and their operation in the past. Given the current situation in air transport in Slovakia, we will identify the important characteristics that make up the business model. In determining the elements, we followed studies (Corbo, 2018; AdilogluYalcinkaya, 2021), where the basic characteristics that must form the airline's business model were defined. Such elements are e.g. air network, aircraft fleet, aircraft occupancy, distribution system and more.

\section{RESULTS AND DISCUSSION}

The choice of a suitable business model for air carrier in Slovakia is a strategic decision for successful operation in a market that is currently characterized by a high degree of competition. In our region operate established traditional FSC, who operate mainly at the airports in Vienna and Budapest and in Slovakia offers their services only two FSC (Austrian Airlines, LOT) exclusively at the airport Košice. LCC have a strong position on the domestic market. It is clear that there is a very small gap in the LCC market and the main goal of the proposed business model will be to provide a different level of services that competitors do not currently offer in Slovakia.

The FSC business model for the Slovak national carrier is excluded. Slovakia has no potential to operate such a carrier. The main reason is the low demand for such a carrier and the limited financial resources that the for example Slovak government has. The Slovak traveling public has a limited interest in this type of carrier, which provides services typical of the FSC. The air carrier in Slovakia will not offer global network services in the initial phase of its operation, as this would be very costly. The costs would relate 


\section{INTERNATIONAL JOURNAL OF ENTREPRENEURIAL KNOWLEDGE}

Issue 9, volume 2, ISSN 2336-2960 (Online)

www.ijek.org

to the construction of the airline network, the procurement of a sufficient number of aircraft, cabin crew and other related costs. Which is unrealistic for the possibilities offered by the Slovak market and, most importantly, Slovakia does not need such an air carrier. This market segment is sufficiently covered by airports abroad, which are in close proximity to Slovakia's largest airports. These foreign airports are operated air routes by large airlines, which offer to almost the entire world. It is unrealistic for the Slovak national carrier to be able to compete with giants such as Lufthansa, Emirates or Austrian Airlines. The fact that the FSC business model does not have a perspective in Slovakia is also proven by past experience. In Slovakia, they tried to establish a very strong FSC such as Lufthansa, Aeroflot or CSA. But not a single airline has been able to establish itself in Slovakia for a long time. The reasons were the low frequency of flights, inappropriate departure times and pricing policy. Slovakia has never been interesting for these companies in terms of market size and potential.

If the business model of the national air carrier were exclusively LCC, it would in no way differ from the strong competition posed by Ryanair and Wizz Air. It would not be able to succeed in direct competition in a market environment, as it would address the same, limited segment of customers. Customers who are looking primarily for cheap flights and do not require any additional services. It would be very difficult to differentiate ourselves from these strong and established airlines, which have a strong economic background and long-term experience in the market. The demand for cheap flights in Slovakia is sufficiently covered. And the space for another LCC is very limited and would not offer enough passengers for all the airlines on the market.

Therefore, the business model we propose for the Slovak national air carrier is - hybrid, with the predominant elements of the full - service carrier. It is a model that is at the interface between FSC and LCC and offers opportunities to address a wider group of passengers than is currently the case on the Slovak market. The main goal of such a business model is to differentiate itself from the competition and offer a higher level of services provided, whether at the airport or during the flight. It will also consist of a moderate pricing strategy that responds to the changing habits of passengers. The introduction of a loyalty program and the development of cooperation with other airlines within the framework of codesharing agreements will be a matter of course. In addition to operating scheduled flights, we also see potential in seasonal charter transport. Our proposed business model would have the following characteristics with a detailed description.

We propose that the national airline network be made up of "point-to-point" connections combined with a "hub-and- spoke" system for certain routes with a high density of connecting flights, in order to reduce the time required for the transfer. In this way, the carrier would provide part of the services of the regional airline as well as the network operator. Which would allow a greater offer of flight routes for its customers. The air network designed in this way will require a shorter turnaround time at airports, which will allow for a relatively high utilization of aircraft. Savings will be achieved thanks to a less complex baggage handling system. Lower turnaround times and more complicated baggage handling are only for "hub-and-spoke" lines, mainly due to long-haul flights due to the time required to unload luggage and transfer large numbers of passengers, service and clean aircraft.

The unified aircraft fleet is another proposed element of the business model of the national air carrier. This element is taken from the LCC and is intended to reduce operating costs. The airline, by operating such a fleet, is able to provide more efficient maintenance and servicing of aircraft, reduce the cost of training and retraining of flight crew. A unified fleet will make it possible to achieve operational savings and will also make it possible to form a lean organizational structure.

The high utilization of the national air carrier's aircraft means flying with a high frequency between individual destinations. Turning time will be crucial to achieve the minimum time spent on the 


\section{INTERNATIONAL JOURNAL OF ENTREPRENEURIAL KNOWLEDGE}

Issue 9, volume 2, ISSN 2336-2960 (Online)

www.ijek.org

ground. The intention is for the turnaround time to be on average 30 minutes and for the use of the aircraft to be 8 to 10 block hours per day.

The business model is based on the use of only secondary airports. Operations at these airports are cheaper and much less congested, which will allow faster equipment and preparation of the aircraft for the next flight. Which directly affects the turnaround time of aircraft. Also, with lower airport occupancy, there is a higher probability of selecting suitable airport time slots that will suit the flight schedule. The last but not least secondary airports also affect cost ratio. As airport charges, such as handling, landing and parking are lower, which will be reflected in the final price for passengers.

The distribution system that we will use for the sale of tickets will consist of our own sales channel. The sale will be realized through a website and application. There will also be a call center. We want to avoid fees and commissions for various travel agencies for arranging the sale of tickets. At present, when almost everyone uses any communication device, such a distribution channel was easily accessible to everyone. An option when selling tickets will also be the possibility of booking a specific seat. There will be several types of tickets on offer, which will include different levels of standard services provided either at the airport or on board the aircraft (e.g., accelerated boarding, in-flight refreshments, more hand luggage, seat reservation, free passenger seat, free flight cancellation and many more). The intention is for the passenger to be able to choose the individual level of services provided, according to their needs, and thus influence the final price of the ticket.

The loyalty program will be used to acquire new and retain regular passengers. As the national air carrier will not initially be a member of any airline alliance, it will have to establish its own loyalty program. The purpose of the loyalty program will be remuneration and the opportunity to use cheaper services for regular passengers. The form and content of the individual programs that will be used within the loyalty program will closely depend on the marketing and communication settings of the company.

The conclusion of code-sharing agreements will be one of the other goals that the company's management will have to achieve in order to increase the offer of air connections and the usability of aircraft itself. Strategic partnerships and cooperation help to achieve more effective results, especially in the aviation sector, which is strongly subject to elements of globalization and has strong aviation alliances. The national air carrier must carry out activities aimed at concluding agreements with other airlines. The advantage will be the provision of smooth travel for passengers, will contribute to the rationalization of the airline's network and will expand the network itself and the flight frequency.

The national air carrier will also achieve cost reductions with a lean organizational structure. The organizational structure will be simple, less bureaucratic and without many layers of management, in order to increase work productivity. Most of the support functions will be provided by external companies so that the airline's core staff are fully engaged only in the core business. By using multitasking, we can achieve higher productivity and also increase the motivation of employees. At the same time, it will bring savings in the number of employees. Proper delegation of individual tasks, clear communication with employees and support of individual creativity will be important. Employees will receive benefits in various forms and an attractive salary.

The proposed business model follows from a detailed analysis and takes into account all aspects that will affect the competitiveness of the national air carrier. There are many factors that will affect the operation of the carrier. In this section, we will define at least the most fundamental risks and threats that may negatively affect the proposed business model of a national air carrier as a hybrid airline and consider them essential at this stage of project preparation. 


\section{INTERNATIONAL JOURNAL OF ENTREPRENEURIAL KNOWLEDGE}

Issue 9, volume 2, ISSN 2336-2960 (Online)

www.ijek.org

In general, the aviation business is very risky and the sector is extremely sensitive to any changes caused by external as well as internal factors. The fact is that the aviation industry is one of the most global industries. It has demonstrable direct and indirect effects on various areas of the economy. Air transport is an integral part and in the development of global him of the economy. It is all the more sensitive to any events that happen anywhere in the world. The year 2020 will go down in the history of aviation and the aviation industry as the worst year in the post-war period. IATA has published financial prospects for the global aviation industry. The aviation industry has never been in a similar situation, resulting in a dramatic and long-term decline in air passenger demand. Previous crises, such as the terrorist attacks in 11 September 2001 or the SARS disease in 2003, have not resulted in such a drastic drop in passengers.

\section{Figure 1 Decline in air passengers caused by the COVID-19 pandemic}

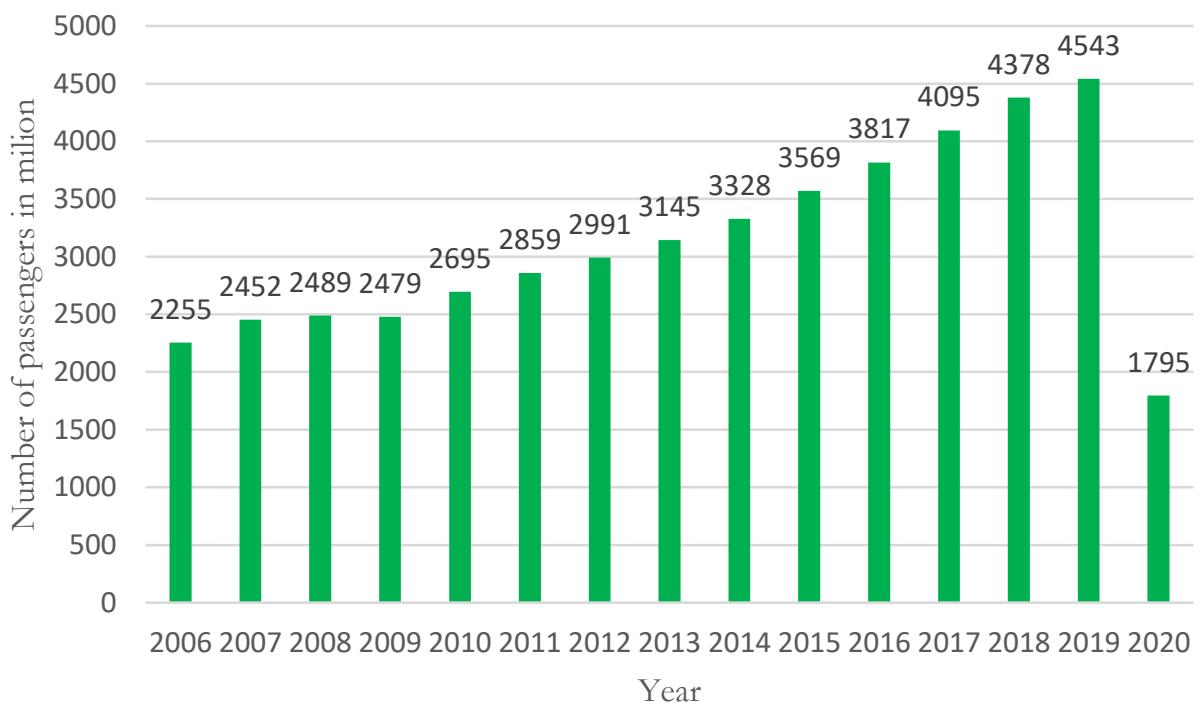

(Source: Statista, 2021)

According to estimates and forecasts, air transport should get back to the number of passengers from the pre-crisis caused by COVID-19, in 2024 or 2025. Therefore, there may be legitimate controversies as to why Slovakia should address the issue of airline at all when today's airline situation does not want transport at all and all companies face economic losses. Air transport will always have an important place in the global economy and the current situation caused by COVID-19 is only temporary. All governments in the world, as well as the European Commission, are aware of this, and they are strongly supporting their national airlines to help them overcome this difficult period and be viable again when the pandemic is over. Because airlines are important for economic growth.

Another threat that will significantly affect the possible functioning of the national air carrier is the political situation in Slovakia. As the intention is for the state to be owned by the state through the Ministry of Transport or an organization authorized by them, the air carrier will be exposed to pressure from politicians and their interests. The decision on whether to create such a carrier will also be seen as a political decision combined with accountability and professional judgment. The current government has no strategy for the development of air transport in Slovakia, nor does it intend to invest in a similar project. Strategic documents, whether at government or ministerial level, do not mention this topic in any way. The state is not interested in this issue, nor are there any professional discussions that would bring proposals and solutions that would create the basis for future governments. Such an approach only maintains the current situation and gives no hope for the development of air transport in Slovakia, so that we can approach the level with other countries of the European Union. The passivity of the state in this direction significantly reduces the implementation of such a project. Unless this strategic goal is 


\section{INTERNATIONAL JOURNAL OF ENTREPRENEURIAL KNOWLEDGE}

Issue 9, volume 2, ISSN 2336-2960 (Online)

www.ijek.org

adopted across political parties and the professional public, such an airline cannot, in principle, be successful.

Competition is another threat that will significantly affect the very functioning of the national air carrier. We are entering a market that is characterized by a high degree of competition and small gaps. There are large airlines operating in Slovakia, mainly LCC, which are established throughout Europe. And competition in the form of multinational airlines is also increasing in neighboring countries. This threat can be eliminated by setting up internal processes, determining the appropriate business strategy and professional management of the company. Without any interference from the state in the day-to-day management of the company. It should be borne in mind that the constant postponement of the establishment of a national air carrier, with increasing time, reduces its possible successful entry into the market, due to the full occupancy of the market by other companies. Therefore, the way in which and how a national airline enters the market will predetermine its potential for growth and peace to be competitive in the future. The planned business model, as a hybrid air carrier, eliminates potential risks arising from a competitive environment.

We consider these threats to be the most fundamental that will affect the carrier's operations. There are a number of other threats and risks that will affect decision-making processes. Anticipating and preparing for all the risks is, in fact, unfeasible. However, it is necessary to pay enough attention to their identification and the management of the company must respond operatively to the solution of the situations that arise, which will then take measures to eliminate them. On the other hand, excessive caution also has a negative impact, as the air carrier will not move in the desired direction in any way.

This study presents the concept of an air carrier business model in Slovakia. The result is a hybrid concept design, with the predominant elements of the full-service carrier. Few studies and articles address this issue. In the analysis of Národohospodárska fakulta (2018) authors recommend the business model as a classic low-cost carrier. The authors do not state exactly on what basis they decided. The only argument they made is the provision of cheap air tickets and thus presuppose reaching a sufficient number of passengers. The authors did not consider the intense competition in this segment in the form of Ryanair and Wizz Air. The demand for services in LCC in Slovakia is sufficiently covered, and there is a minimal gap in the market. Another form of business model is proposed by Turčan et al. (2020). Their article concluded that the business model should be hybrid, with the predominant elements of the network carrier. I can agree with the conclusions of this study because they accurately assessed the current situation in air transport in Slovakia and the habits of Slovak passengers. Various studies (Klophaus, 2012; Magdalina et al., 2021; Fageda et al., 2019; O'Connell, 2017) show that the hybrid model is gaining in popularity. The form of this business model is competitive and can reach a wide range of passengers through pricing policy and level of service. Each airline adapts its own characteristics to current market developments and creates its own business model. Tomová et al. (2014) state that airlines are moving to a hybrid business model and trying to differentiate themselves from the competition through their differentiated services by creating a unique business model. According to Albers et al. (2020), this business model is suitable in the case of adverse events such as COVD-19 and related changes. As it can respond more flexibly to demand.

\section{CONCLUSIONS}

The article aimed to design a competitive business model of a hypothetical national air carrier in Slovakia. Based on the knowledge gained from the analysis of current trends in the management of air operators, we have created our own concept of a business model - a hybrid model with the predominant elements of a network air carrier. We have determined the detailed characteristic features that distinguish it from airlines currently operating on the Slovak market. The proposed business model intends to 


\section{INTERNATIONAL JOURNAL OF ENTREPRENEURIAL KNOWLEDGE}

Issue 9, volume 2, ISSN 2336-2960 (Online)

www.ijek.org

differentiate itself from current airline operators by providing services at a higher level and a more comprehensive range of connecting flights, thanks to the conclusion of code-sharing agreements. However, concerning the constant reduction of costs, the prices of tickets are interesting for the Slovak traveling public. With the predominant elements of a network air carrier, the hybrid business model does not yet operate in Slovakia.

Moreover, detailed analysis and comparison of individual business models, the conditions of the Slovakia market in this model can fill the market's current gap. The article also identified three basic threats and risks to the business model, which can cause failure. Despite our article, however, this issue requires further research and examination of other areas that will directly affect the operation of such an air operator. A comprehensive marketing strategy, the determination of suitable flight routes for scheduled passenger air transport, and an economic plan for a start-up airline are also crucial for the airline's success. These are the areas that future research will address. However, we consider the stated goal of the article to be fulfilled.

\section{REFERENCES}

Adiloğlu-Yalçınkaya, L., Besler, S., (2021). Institutional factors influencing business models: The case of Turkish Airlines. Journal of Air Transport Management 91, 101989.

Achtenhagen, L., Melin, L., Naldi, L., (2013). Dynamics of Business Models - Strategizing, Critical Capabilities and Activities for Sustained Value Creation. Long Range Planning., Volume 46, Issue 6, $427-442$.

Albers, S., Rundshagen, V., (2020). European airlines' strategic responses to the COVID-19 pandemic (January - May 2020). Journal of Air Transport Management 87, 101863.

Corbo, L., (2017). In search of business model configurations that work: Lessons from the hybridization of Air Berlin and JetBlue. Journal of Air Transport Management 64, 139 - 150.

Corbo, L., Corrado, R., Ferriani, S., (2016). A New Order of Things: Network Mechanisms of Field Evolution in the Aftermath of an Exogenous Shock. Organization Studies, Volume:37 issue:3, 323 348.

Cozzolino, A., Rothaermel, F.T., Gianmario, V., (2017). Business Model Innovation after Disruptions: A Process Study of an Incumbent Media Organization. The 77th Annual Meeting of the Academy of Management (AOM 2017), Atlanta, Georgia, 4-8 2017.

Daft, J., Albers, S. (2013). A conceptual framework for measuring airline business model convergence. Journal of Air Transport Management 28. 47-54.

Daft, J., Albers, S., (2015). An empirical analysis of airline business model convergence. Journal of Air Transport Management 46, 3 - 11.

DaSilva, C.M., Trkman, P., (2014). Business Model: What It Is and What It Is Not. Long Range Planning. Vol.47, issue 6, $379-389$.

Fageda, X., Flores-Fillol, R., Theilen, B., (2019). Hybrid cooperation agreements in networks: The case of the airline industry. International Journal of Industrial Organization Volume 62, 194-227.

Fageda, X., Suau-Sanchez, P., Mason, K.J., (2015). The evolving low-cost business model: Network implications of fare bundling and connecting flights in Europe. Journal of Transport Management 42, Elsevier Science Ltd., $289-296$.

Foss, N.J., Saebi, T., (2015). Business models and business model innovation: bringing organization into the discussion. Oxford University Press.

Foss, N.J., Saebi, T., (2018). Business models and business model innovation: Between wicked and paradigmatic problems. Long Range Planning, Volume 51, issue 1, 9- 21.

Franke, M. (2007). Innovation: the winning formula to regain profitability in aviation? Journal of Air Transport Management 13. 23-30. 


\section{INTERNATIONAL JOURNAL OF ENTREPRENEURIAL KNOWLEDGE}

Issue 9, volume 2, ISSN 2336-2960 (Online)

www.ijek.org

Chesbrough, H.W., (2010). Business Model Innovation: Opportunities and Barriers. Long Range Planning, Volume 43, Issue 2-3, 354-363.

Jakubík, M., Tomová, A., (2020). The concept of a national air carrier in the Slovak republic. STUDIES -KLD, FACULTY PEDAS, ŽU. 39-45.

Klophause, R., (2012). Low cost carriers going hybrid: evidence from Europe., Journal of Transport Management 23, Elsevier Science Ltd., 54-58.

Laasch, O., (2018). Beyond the purely commercial business model: Organizational value logics and the heterogeneity of sustainability business models. Long Range Planning. Vol.51, issue 1, $158-183$.

Lohmann, G., Koo, T.T.R., (2013). The airline business model spectrum. Journal of Air Transport Management 31, 7 - 9 .

Lohmann, G., Spasojevic, B., (2018). Airline business strategy. The Routledge Companion to Air Transport Management.

Magdalina, A., Bouzaima, M., (2021). An empirical investigation of European airline business models: Classification and hybridisation. Journal of Air Transport Management 93, 101989.

Markides, C., Sosa, L., (2013). Pioneering and first mover advantages: the importance of business models. Long Range Planning, Volume 46, 325-334.

Markides, C., Sosa, L., (2013). Pioneering and First Mover Advantages: The Importance of Business Models. Long Range Planning, Volume 46, Issue 4-5, 325-334.

Massa, L., Tucci, C.L., (2013). Business model innovation. The Oxford Handbook of Innovation Management. $420-441$.

Massa, L., Tucci, C.L., Afuah, A., (2017). A Critical Assessment of Business Model Research. Academy of Management Annals, Vol. 11, No. 1, 73-104.

Národohospodárska fakulta, EUBA (2018). Analysis of the establishment of a national air carrier. online: wnw.slov-lex.sk/legislativne-procesy/-/SK/LP/2019/41.

Nenonen, S., Storbacka, K., (2010). Business model design: conceptualizing networked value cocreation., International Journal of Quality and Service Sciences, Vol. 2, No. 1, 43-59.

Ocasio, W., Radoynovská, N., (2016). Strategy and commitments to institutional logics: Organizational heterogeneity in business models and governance. Strategic Organization. Volume: 14, issue 4, $287-$ 309.

O'Connell, J.F., Connolly, D., (2017). The strategic evolution of Aer Lingus from a full-service airline to a low-cost carrier and finally positioning itself into a value hybrid airline. Tourism Economics, Volume 23, issue 6, 1296-1320.

Pereira, B.A., Caetano, M., (2015). A conceptual business model framework applied to air transport. Journal of Transport Management 44-45, Elsevier Science Ltd., 70-76.

Santos, J., Spector, B., Van der Heyden, L., (2009). Towards a theory of business model innovation within existing firms. INSE AD, Fontainebleau.

STATISTA [online], Number of passengers on board the global aviation industry from 2006 to 2020. www.statista.com/statistics/564717/ airline-industry-passenger-traffic-globally/

Sund, K.J., Villarroel, J.A., Bogers, M., (2014). Organizational Aspects of Business Model Innovation: The Case of the European Postal Industry. Academy of Management Annual Meeting.

Teece, D.J., (2010). Business Models, Business Strategy and Innovation. Long Range Planning, Volume 43, issue 2-3, $172-194$.

Tobisová, A., SZABO, S., (2014). Aviation Economics II., Multiprint s.r.o., Košice, 8-12.

Tomová, A., Ramajová, L., (2014). Frequent Flyer Programs and Low-cost Airlines: Ongoing Hybridization? Procedia - Social and Behavioral Sciences, Volume 110, 787-795.

Turčan, D., Novák Sedláčková, A., (2020). New forms of horizontal cooperation of the airlines. StudiesKLD, Faculty PEDAS, Žilinská univerzita. 
INTERNATIONAL JOURNAL OF ENTREPRENEURIAL KNOWLEDGE

Issue 9, volume 2, ISSN 2336-2960 (Online)

www.ijek.org

Urban, M., Klemm, M., Ploetner, K.O., Hornung, M., (2018). Airline categorisation by applying the business model canvas and clustering algorithms. Journal of Air Transport Management 71, 175 - 192.

Wensveen, J.G., Leick, R., (2009). The long-haul low-cost carrier: A unique business model. Journal of Air Transport Management 15, 127 - 133.

Zott, C., Amit, R., (2011). The Business Model: Recent Developments and Future Research. Journal of Management. 37, issue 4, 1019 - 1042.

\section{BRIEF DESCRIPTION OF AUTHOR:}

Ing. Radovan Baláž, PhD.

ORCID ID: https://orcid.org/0000-0002-7465-0845

Affiliation: Faculty of Aeronautics, Technical University of Košice, Rampová 7, 04121 Košice, Slovakia, https://lf.tuke.sk/wps/portal/lf/fakulta/katedry/katedra-manažmentu-leteckej-prevadzky/katedramanazmentu-leteckej-prevadzky

Email: radovan.balaz@tuke.sk

His research activities mainly focus on airline management, the development of the civil aviation industry, and marketing in the aviation industry. 